\title{
Light dynamics and free-to-grow standards in aspen- dominated mixedwood forests
}

\author{
by Victor J. Lieffers ${ }^{1}$, Bradley D. Pinno ${ }^{2}$ and Kenneth J. Stadt ${ }^{3}$
}

This study examines light competition between aspen and spruce during the sequence of aspen development. Leaf area index and light transmission were measured or estimated for aspen stands from 2 to 125 years old. Light transmission was lowest at 15-25 years, and in some stands, transmission was less than $5 \%$ of above-canopy light. Hypothetical aspen stands with various stem configurations and heights were developed, and positions were identified that would meet or fail Alberta free-to-grow (FTG) standards. Light transmission was estimated at each position with the MIXLIGHT forest light simulator. Positions in canopy gaps or at the northern sides of canopy gaps had higher light. In general, however, there was little difference in available light between positions that met or failed FTG criteria. Stand density and size of aspen trees appears to be a better index to predict light transmission and spruce success in juvenile aspen stands than current FTG criteria.

Key words: competition, free to grow, hardwood, spruce, light

Cette étude porte sur la compétition pour la lumière entre le peuplier faux-tremble et l'épinette au cours de la période de développement du peuplier faux-tremble. L'indice de la surface foliaire et la transmission de la lumière ont été mesurés ou estimés dans des peupleraies âgées de 2 à 125 ans. La transmission de la lumière a été la plus faible dans les peuplements de 15 à 25 ans, et dans certains peuplements, la transmission a été de moins de 5\% par rapport à la lumière au-dessus des cimes. Des peupleraies hypothétiques représentant diverses configurations de tige et de hauteur ont été élaborées, et des positions ont été identifiées qui correspondraient ou non aux normes de tige libre de croître de l'Alberta. La transmission de la lumière a été estimée pour chaque position au moyen du simulateur de lumière sous couvert forestier MIXLIGHT. Les positions retrouvées dans les ouvertures du couvert ou du côté nord des ouvertures dans le couvert recevaient plus de lumière. De façon générale, cependant, il existe peu de différence au niveau de la lumière disponible entre les positions qui répondaient ou non aux normes de croissance sans concurrence. La densité du peuplement et la taille des tiges de peuplier semblent être un meilleur indice de prédiction de la transmission de la lumière et du succès de l'épinette dans les jeunes peupleraies que ne le sont les normes actuelles de croissance sans concurrence.

Mots-clés: concurrence, libre de croître, feuillus, épinette, lumière

\section{Introduction}

Trembling aspen (Populus tremuloides) and white spruce (Picea glauca) are the dominant species in boreal mixedwood forests of western North America. Aspen regenerates clonally from sprouts and quickly dominates sites after disturbance; in contrast, white spruce regenerates from seed and has slow juvenile growth rates. As the spruce has historically been considered to be the more valu-

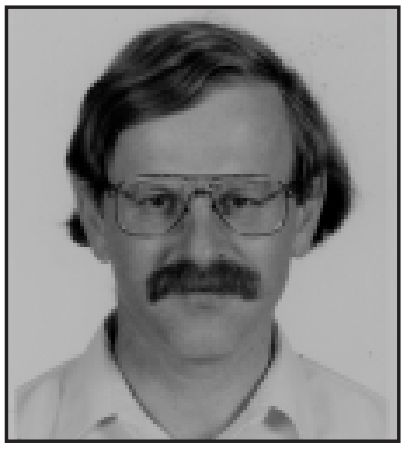

Victor J. Lieffers

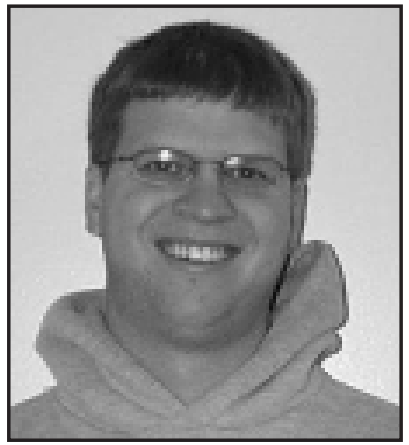

Bradley D. Pinno

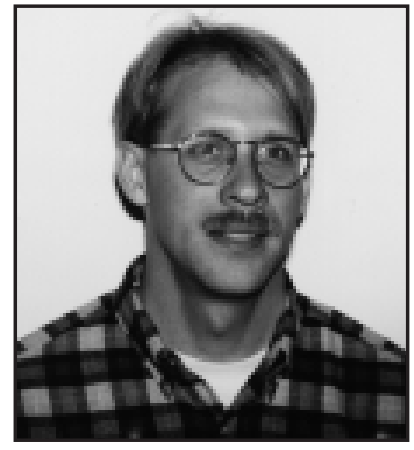

Kenneth J. Stadt able species for sawlogs, there has been concern about the competitive impacts of aspen on the spruce (Eis 1981, Comeau et al. 1993). It has generally been assumed that light is the resource most limiting to growth and survival of juvenile spruce in the boreal forests (Brand 1986, Tanner et al. 1996). While there has been work describing the light regime in various stages of boreal mixedwood forest development (Lieffers and Stadt

${ }^{1}$ Department of Renewable Resources, Centre for Enhanced Forest Management, University of Alberta, Edmonton, Alberta T6G 2H1. E-mail: Victor.Lieffers@ualberta.ca

${ }^{2}$ Department of Renewable Resources, Centre for Enhanced Forest Management, University of Alberta. Current address: Saskatchewan Environment Resource Management, La Ronge, Saskatchewan, S0J 1LO.

${ }^{3}$ Department of Renewable Resources, Centre for Enhanced Forest Management, University of Alberta, Edmonton, Alberta T6G 2H1.

1994, Constabel and Lieffers 1996, Tanner et al. 1996, Messier et al. 1998, Lieffers et al. 1999), there has not been a comprehensive description of changes in light with stand age, particularly for the juvenile phase of stand development.

Distance-dependent competition indices have been developed that attempt to quantify the impacts of adjacent competitors on the growth of a subject tree (Brand 1986). In several provinces in Canada, including Alberta and British Columbia, provincial regulators have developed Free-to-Grow (FTG) standards, i.e., distant-dependent competition indices that are used to regulate an acceptable level of competition from hardwoods and brush. Achieving FTG status implies that the stand is limited only by site resources (Brand and Weetman 1986), and the stand is successfully regenerated and contributing to overall forest production (MacDonald and Weetman 1993). FTG status could also be considered a sur- 
vival standard where the crop tree is expected to grow at a rate equal to that of natural stands (Alberta Environment 2000). Coniferous trees are considered FTG when adjacent hardwood or shrub species are sufficiently small or far away from the conifer crop tree that they are considered to have minimal or acceptable competitive effects, especially on the light resource. These standards are also intended to predict competition levels into the future and ensure that the conifer trees will not suffer later from unacceptable levels of competition. The three main criteria used in determining FTG status are that the crop tree is a suitable species for the site, it has reached acceptable size relative to competitors, and that competitor species are a sufficient distance away from the subject tree (Brand and Weetman 1986).

In Alberta, the FTG status of a plantation is assessed 8-14 years after harvesting. There are several versions of FTG standards: Prior to January 2000, no competing hardwood tree could be greater than $2 / 3$ the height of the conifer tree within a 1-m radius (Alberta Forest Service 1992). Since 2000, this radius has been increased to $2 \mathrm{~m}$ for coniferous stands (Alberta Environment 2000). Mixedwood FTG standards for the 2000 standards require that spruce trees be at least $1 \mathrm{~m}$ tall and be free of competing vegetation greater than $2 / 3$ the height of the spruce tree, within a $270^{\circ}$ arc, within a $1.5 \mathrm{~m}$ radius. To our knowledge, however, none of these standards have been justified for boreal mixedwood forests using either empirical data or simulations.

The MIXLIGHT forest light simulator is described in Stadt and Lieffers (2000), and its calibration and spatially explicit validation for juvenile aspen stands outlined by Pinno et al. (2001). Knowing the size of aspen trees in a mapped stand, it is possible to use MIXLIGHT to estimate the growing season light for specific understory positions. Mortality of spruce is likely when transmitted light is below $10 \%$. Secondly, there is virtually no increase in height growth above $40 \%$ light, although radial growth increases somewhat further at higher light (Logan 1969, Lieffers and Stadt 1994, Wright et al. 1998). Using MIXLIGHT, we can evaluate the light available at stand positions which meet or fail various FTG standards, and evaluate (based upon light thresholds from the literature) which standard best identifies a tree's likelihood of success with respect to light competition.

The three objectives of this study are as follows: 1) Describe the leaf area development and understory light availability for aspen-dominated stands in the boreal mixedwood forest. 2) Determine the light available to conifer saplings under a canopy of hypothetical aspen stands of different size, density and spatial configuration, at positions that meet or fail current FTG standards. This will also allow testing of the importance of distance, direction, size and density of adjacent hardwoods. 3) Determine a simple mensuration-based mechanism to estimate light under aspen saplings.

\section{Methods}

Light or leaf area in juvenile aspen stands was measured or estimated in aspen stands of a range of ages. To develop a chronosequence of light transmission and leaf index for aspen stands, we gathered published data on light transmission or leaf area from a range of sites in northern and western Alberta (Lieffers and Stadt 1994, DeLong et al. 1997, Stadt and Lieffers
2000, Pinno et al. 2001, DesRochers and Lieffers 2001,). Stands were from the boreal mixedwood BMd and BMe ecosites (Beckingham et al. 1996). Either measurements of light or leaf area index were determined in each stand. Beer's Law (Equation 1) was used to estimate either light transmission or LAI, depending upon the source of data.

\section{[1]}

$$
\mathrm{I} / \mathrm{I}_{\mathrm{o}}=\exp (-0.5 * \mathrm{LAI})
$$

Here, $\mathrm{I}=$ incident light below canopy, $\mathrm{I}_{\mathrm{O}}=$ incident light above canopy and LAI is the leaf area index for the stand. The coefficient of 0.5 is an approximate value for deciduous stands (Pierce and Running 1988, Jarvis and Leverenz 1983).

Modelling light transmission in relation to FTG standards was done in hypothetical stands of young aspen trees that were developed with a variety of height and density classes. All of the individual tree characteristics such as crown length and width, leaf area and leaf area density were modelled based on stem diameter at $30 \mathrm{~cm}$ height $\left(\mathrm{D}_{30}\right)$ (Pinno et al. 2001). Three stands with different spatial arrangements of aspen trees were modelled: Stand 1 generally had a 2-m spacing of dominant stems (ca. 2500 stems/ha, Fig. 1). Stand 2 had 3-m spacing (1109 stems/ha, Fig. 2). Stand 3 had a 2.5-m spacing (ca. 1600 stems/ha) but had trees missing or added to create various spatial arrangements specifically to test the FTG standard that used the $270^{\circ}$ competitor-free arc (Fig. 3). Five different versions of each stand arrangement were created using trees of 3, 5, 7, 9 and $11 \mathrm{~cm} \mathrm{D}_{30}$. Calibration data to generate these stands were presented in Pinno et al. (2001). Tree heights varied from 4.1 $\mathrm{m}$ tall at $3-\mathrm{cm} \mathrm{D}_{30}$ to $11.9 \mathrm{~m}$ tall at $11-\mathrm{cm} \mathrm{D}_{30}$. These $15 \mathrm{sim}-$ ulated stands ( 3 arrangements $\times 5$ tree sizes) provided a wide range of densities and sizes to test FTG standards.

Within each of these hypothetical stands, various horizontal positions, some FTG and others not-FTG under various standards, were identified. At each horizontal position, the height for light estimation was $1 \mathrm{~m}$ for the $3-\mathrm{cm} \mathrm{D}_{30}$ stand, 1.5 $\mathrm{m}$ for the $5-\mathrm{cm}$ stand, $2.5 \mathrm{~m}$ for the $7-\mathrm{cm}$ stand, $3.5 \mathrm{~m}$ for the 9-cm stand, and $4.5 \mathrm{~m}$ for the $11-\mathrm{cm}$ stand, to simulate the gradual increase in top height of a spruce tree as these stands develop. In addition, the change in light levels with height was estimated in the stand with the largest trees $\left(11 \mathrm{~cm} \mathrm{D}_{30}\right)$ and 2.5-m spacing, from ground level to above the canopy. The light was estimated for each position using MIXLIGHT (Stadt and Lieffers 2000). Average seasonal light for each position was modelled for May 15 to Sept 15 , at $54^{\circ}$ latitude, and assuming that sites were level. Over this time period, MIXLIGHT was set to receive $50 \%$ of light directly from the sun and $50 \%$ from diffuse beam radiation, as is typical for an Alberta summer (K.J. Stadt, unpublished). It was assumed that diffuse radiation came from all parts of the sky but the radiance from the zenith area was 2.23 times brighter than zones near the horizon (Stevens and Unsworth 1980). The plot was replicated eight times around the actual plot to allow more realistic conditions for light originating at low angles.

To determine a simple method of predicting light from mensuration data, we assessed 17 young aspen stands from the BMd and BMe ecosites (Beckingham et al. 1996) in northern and western Alberta. Light was measured above the shrub layer inside the stand, then above the canopy, either on uniformly cloudy days or on sunny days between 11:00 and 14:00 local time. A light measurement consisted of a circular sweep of 15-20 


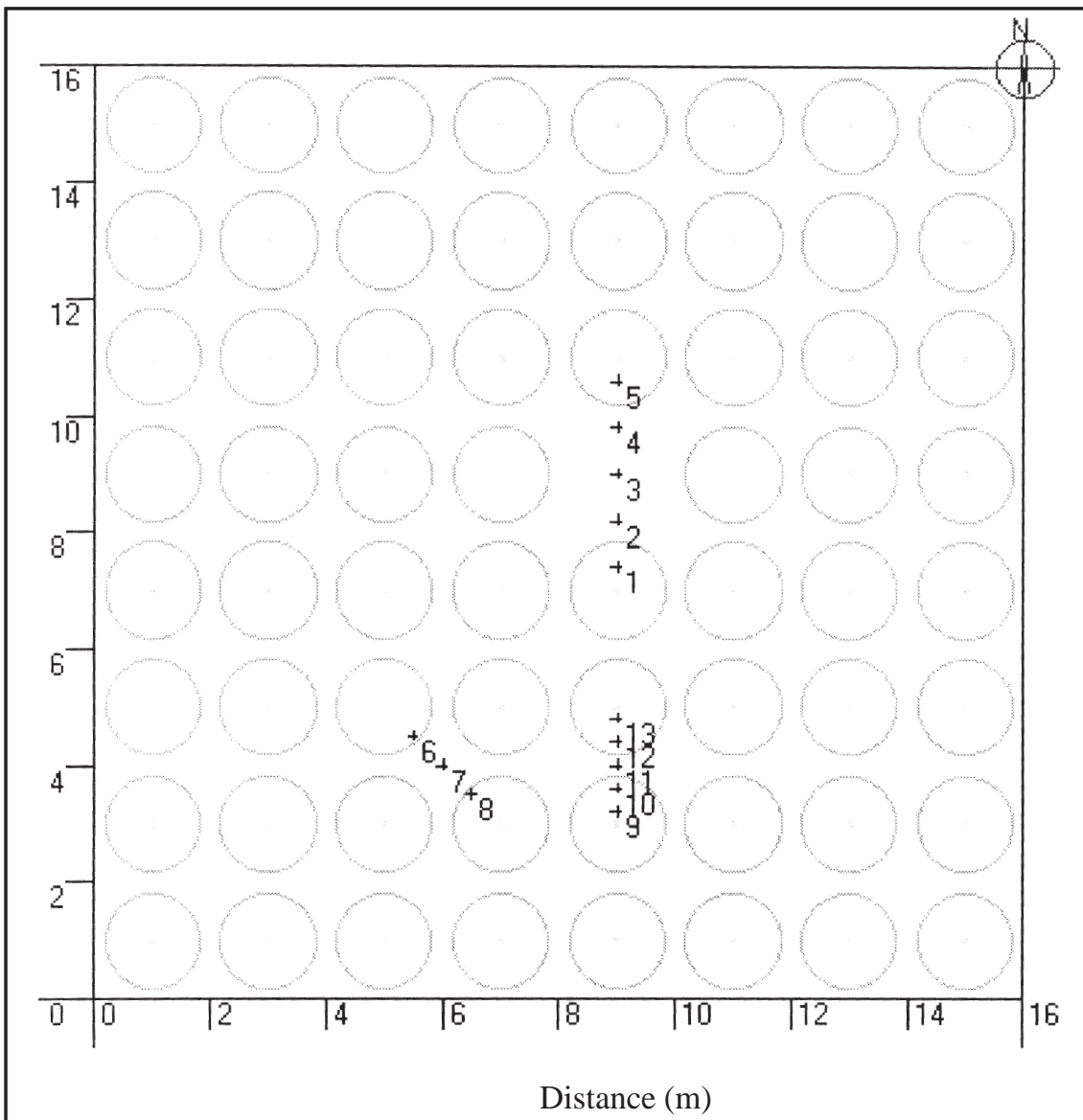

Fig. 1. Hypothetical Plot 1 with $2 \times 2-\mathrm{m}$ spacing of aspen trees (shown with crown sizes for $5 \mathrm{~cm} \mathrm{D}_{30}$ ) trees. Numbered positions indicate the modelled position of spruce trees that meet or fail various FTG standards.
Fig. 2. Hypothetical Plot 2 with $3 \times 3-\mathrm{m}$ spacing of aspen trees (shown with crown sizes for $5 \mathrm{~cm} \mathrm{D}{ }_{30}$ ) trees. Numbered positions indicate the modelled position of spruce trees that meet or fail various FTG standards.

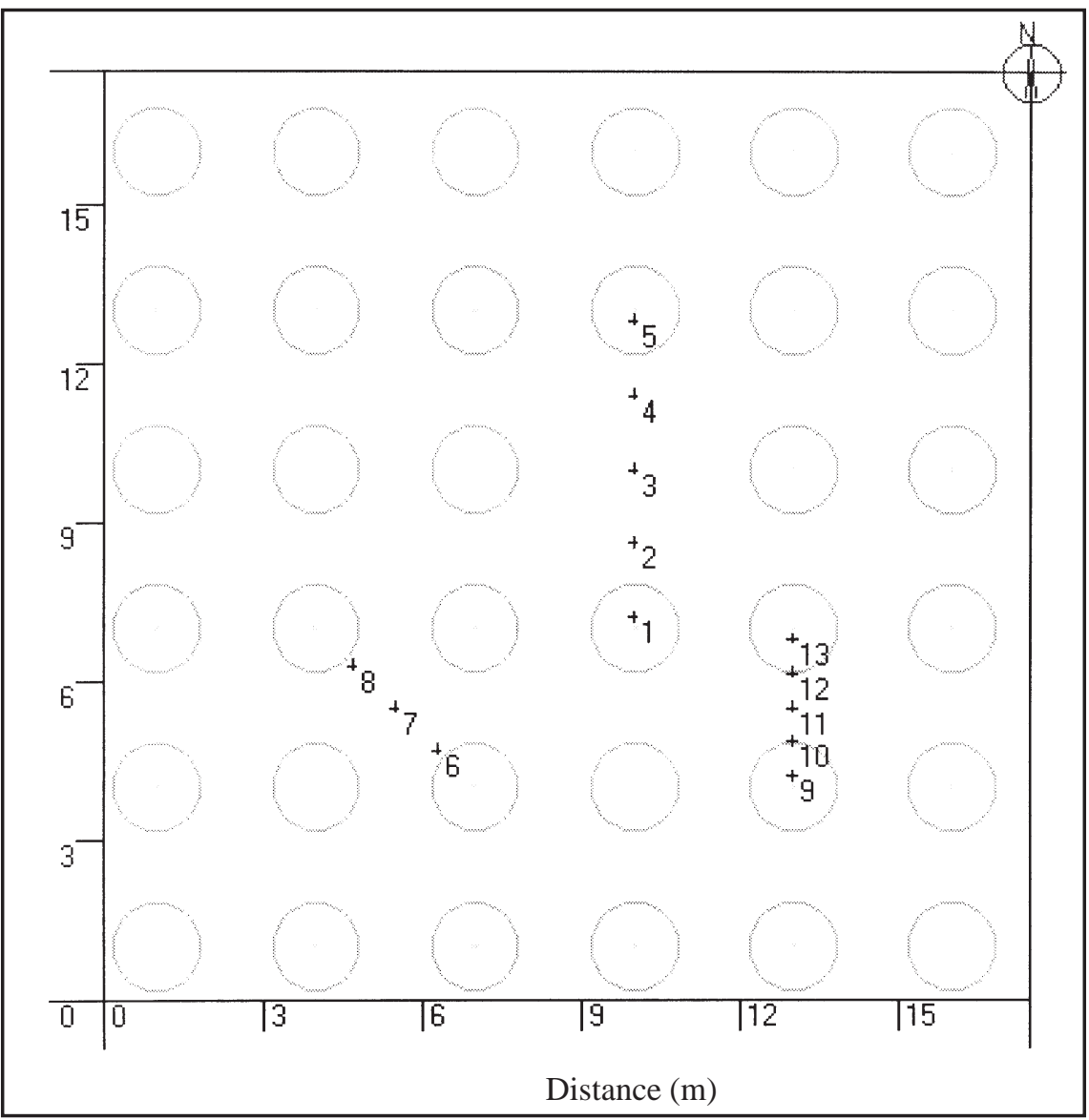




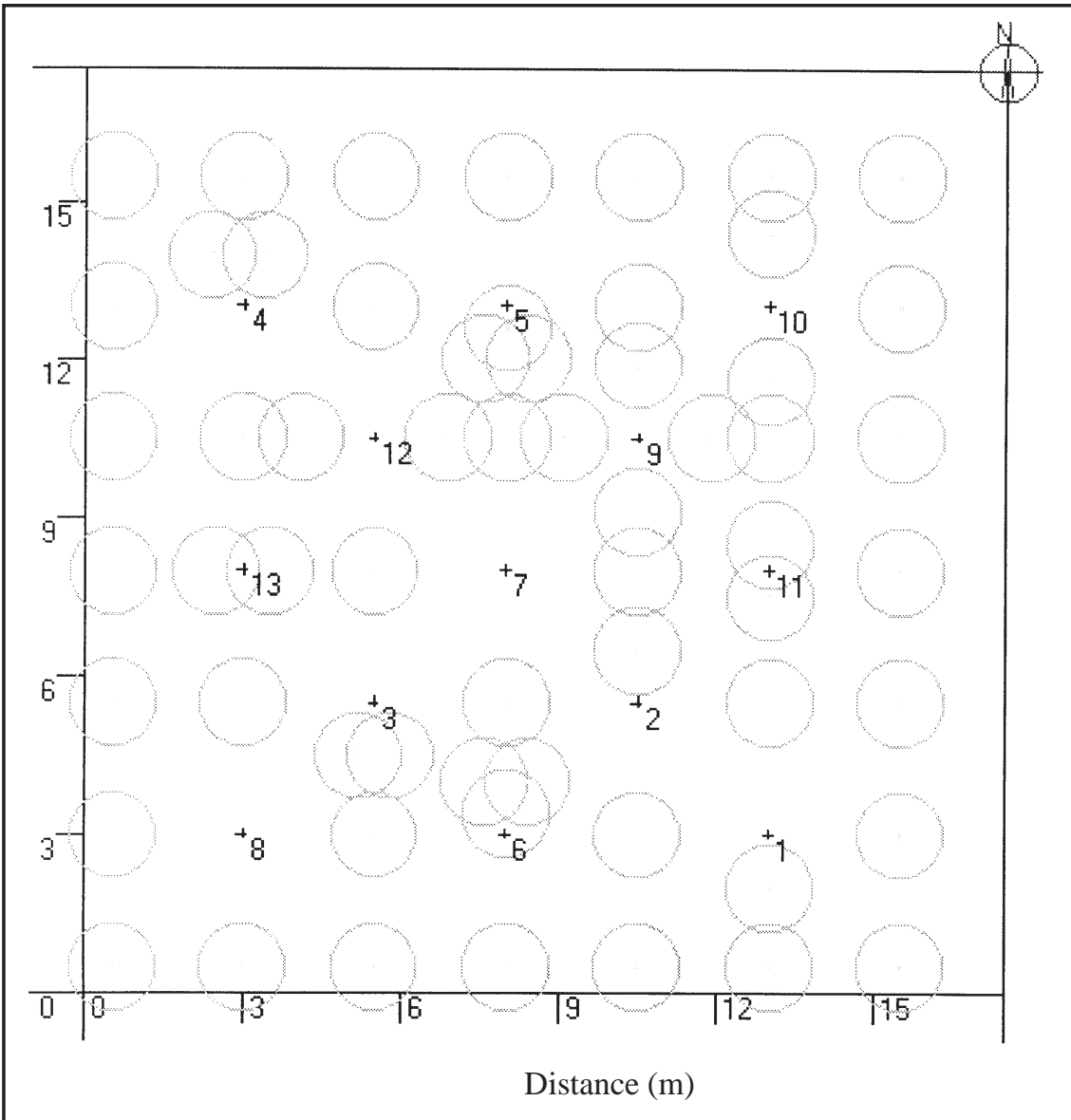

Fig. 3. Hypothetical Plot 3 with $2.5 \times 2.5-\mathrm{m}$ spacing of aspen trees (shown with crown sizes for $5 \mathrm{~cm} \mathrm{D}_{30}$ ) with some gaps or extra trees added specifically to test the mixedwood FTG standard. Numbered positions indicate the modelled position of spruce trees that meet or fail various FTG standards. light measurements using an $80 \times 1 \mathrm{~cm}$ quantum radiometer sensitive to photosynthetically active radiation (Model SF-80, Decagon Devices Inc., Pullman, WA). In a circular plot 2-3 $\mathrm{m}$ in radius (plots with taller trees and lower density had a 3 $m$ radius) surrounding the light measurement, $\mathrm{D}_{30}$ of each tree and mean height of dominants was determined. Light transmission (the ratio of the light inside the stand to the light outside) was regressed against mean height, density and basal area. The best equation was chosen based on $\mathrm{R}^{2}$ and examination of residuals. Pinno (2000) provides more detailed information.

\section{Results}

Leaf area index (LAI) showed a steep increase with stand age, reaching a maximum of about $6 \mathrm{~m}^{2} \mathrm{~m}^{-2}$ at 15 to 25 years; transmission declined to as low as $2 \%$ at these high LAI values. After this time, there was a gradual increase in light transmission (Fig. 4a) and a decrease in LAI (Fig. 4b). There was, however, wide variation in both transmission LAI and light transmission at a given age.

Light transmission was modelled in relation to FTG standards for three plots. Plots 1 and 2 both had uniform layout of trees with one tree missing (Figs. 1 and 2). Positions for light modelling were established $\mathrm{N}$ to $\mathrm{S}$ across the missing tree gap (1-5), diagonally between trees (6-8) and $N$ to $S(9-13)$ between trees. There were relatively small differences in light transmission between the positions that were or were not classed as FTG; position 3, which would be categorized as FTG in all schemes, actually had lower light transmission than posi- tion 5 (the $\mathrm{N}$ edge of the gap) that would not be FTG in any of the systems using a full circle. There was a striking decline in light transmission as the aspen "grew" in size. Also, there was greater light transmission with the $3 \mathrm{~m}$ spacing (Table 2) compared to the 2-m spacing (Table 1).

Plot 3 was generated to evaluate the different FTG scenarios using the $270^{\circ}$ arc (Fig. 3). Trees were added in various positions to create situations where one, two or three trees were included within $1.5 \mathrm{~m}$ of the $90^{\circ}$ arc, either on the north or south side of the queried point (1-6). Positions 7 and 8 were $2.5 \mathrm{~m}$ away from any trees. Position 9 had four extra trees added within $1.5 \mathrm{~m}$. Positions 10 to 13 had two extra trees added at various distances and directions. The most important finding in these analyses was the general decrease in light as the average size of trees in the plot increased (Table 3). Secondly, the centre of the large gap had a 10-15\% increase in transmitted light, relative to position 5 with the lowest light, where there were several trees immediately to the south. When extra trees were added on the north side (positions 2, 4 and 6) there was greater incident light compared to when extra trees were on the south (1, 3 and 5) indicating that for light availability, direction of the aspen trees may be more important than distance. The last column of Table 3 shows the light transmission for the $11 \mathrm{~cm} \mathrm{D}_{30}$ aspen stand when light was modelled at the same locations, but with the plot at $44^{\circ}$ latitude. With direct beam radiation coming closer to vertical, positions 7 and 8 in gaps had a relatively larger increase in light transmission compared to these positions when modelled at $54^{\circ}$ latitude. 

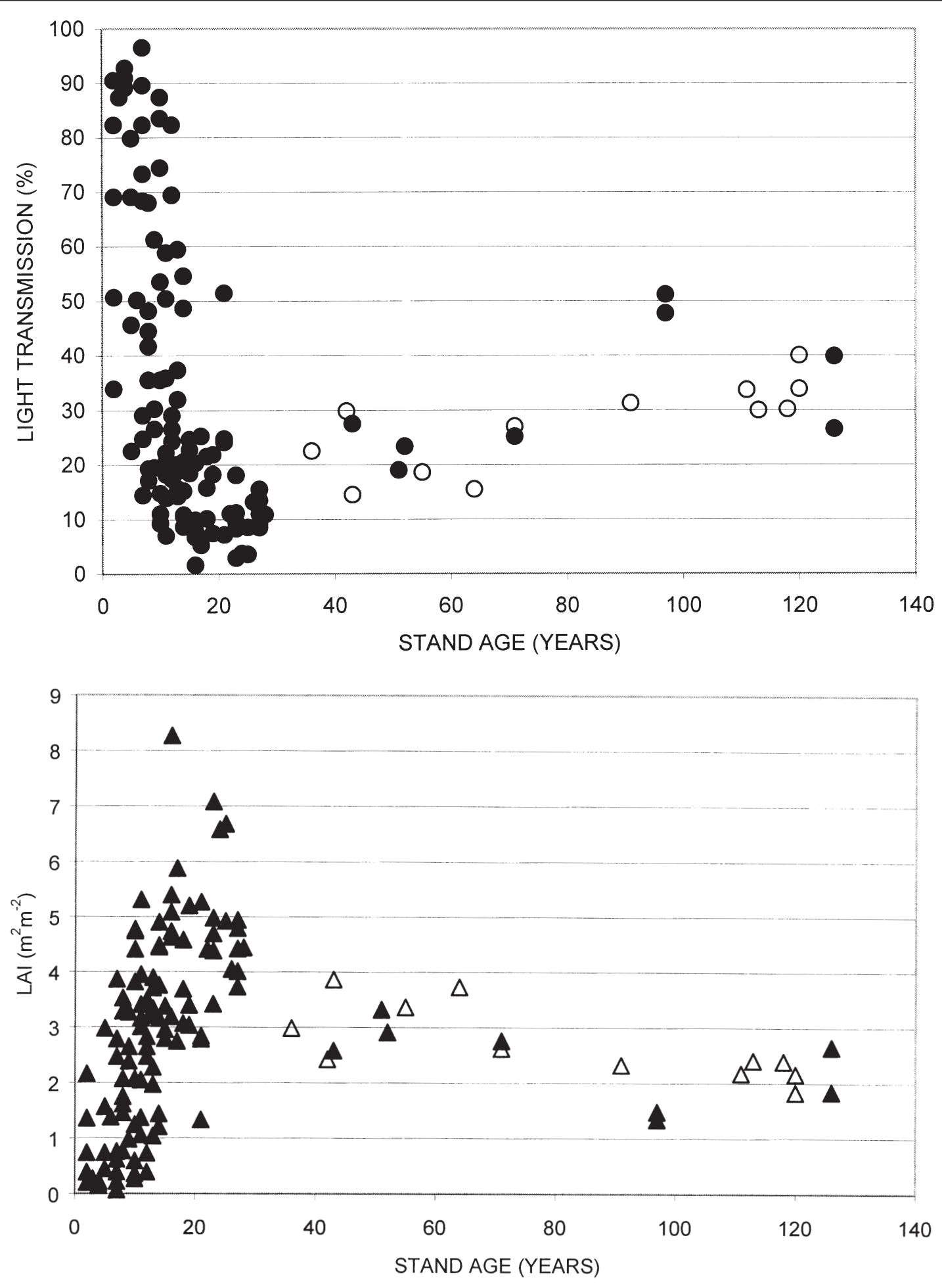

Fig. 4. Light transmission (a) and leaf area index (b) in relation to age for aspen stands in Alberta. Data were from light transmission measurements (Lieffers and Stadt 1994) - open symbols and from leaf area estimates/measurements (DesRochers and Lieffers 2001, Stadt and Lieffers 2000, DeLong et al. 1997, Pinno et al. 2001) - closed symbols.

The analysis of the height of light estimation for the various positions in plot 3 (Fig. 5) indicated that there was little impact of the local spatial geometry of aspen trees in this 11-m tall stand on light estimated near the ground.
With increasing simulation height, however, there was a substantial increase in light transmission in large gaps (positions 7 and 8$)$ and at positions on the north side of gaps $(2,4$ and 6). 
Table 1. Light transmission (\%) for 13 different positions within a hypothetical aspen plot with a $2 \times 2$-m spacing (see Fig. 1). The plot was "grown" from 3 to $11 \mathrm{~cm}$ D30. Light was modelled at 1 to $4.5-\mathrm{m}$ height, depending upon the size of the aspen. Four different Free-to-Grow criteria were considered for each of the positions where light was modelled. Light estimation was for $50 \%$ diffuse light conditions from $\mathrm{May} 15$ to Sept. 15 , at $54^{\circ}$ latitude.

\begin{tabular}{|c|c|c|c|c|c|c|c|c|c|}
\hline \multirow[b]{2}{*}{ Position } & \multicolumn{4}{|c|}{ Pass FTG Type $^{1}$} & \multicolumn{5}{|c|}{ Mean $D_{30}$ of Aspen/Height of Light Estimate } \\
\hline & $\begin{array}{c}1.5 \mathrm{~m} \\
270^{\circ}\end{array}$ & $1 \mathrm{~m}$ & $1.5 \mathrm{~m}$ & $2.0 \mathrm{~m}$ & $\begin{array}{l}3 \mathrm{~cm} \\
1.0 \mathrm{~m}\end{array}$ & $\begin{array}{l}5 \mathrm{~cm} \\
1.5 \mathrm{~m}\end{array}$ & $\begin{array}{l}7 \mathrm{~cm} \\
2.5 \mathrm{~m}\end{array}$ & $\begin{array}{l}9 \mathrm{~cm} \\
3.5 \mathrm{~m}\end{array}$ & $\begin{array}{l}11 \mathrm{~cm} \\
4.5 \mathrm{~m}\end{array}$ \\
\hline $1(\mathrm{SG})$ & $\mathrm{Y}$ & $\mathrm{N}$ & $\mathrm{N}$ & $\mathrm{N}$ & 85.2 & 58.6 & 35.1 & 18.1 & 8.1 \\
\hline $2(\mathrm{SG})$ & $\mathrm{Y}$ & $\mathrm{Y}$ & $\mathrm{N}$ & $\mathrm{N}$ & 78.5 & 55.4 & 32.7 & 18.6 & 9.8 \\
\hline 3 (CG) & $\mathrm{Y}$ & $\mathrm{Y}$ & $\mathrm{Y}$ & $\mathrm{Y}$ & 86.0 & 60.2 & 35.3 & 18.4 & 9.6 \\
\hline 4 (NG) & $\mathrm{Y}$ & $\mathrm{Y}$ & $\mathrm{N}$ & $\mathrm{N}$ & 85.3 & 57.7 & 36.0 & 20.0 & 10.7 \\
\hline $5(\mathrm{NG})$ & $\mathrm{Y}$ & $\mathrm{N}$ & $\mathrm{N}$ & $\mathrm{N}$ & 87.1 & 63.1 & 37.3 & 20.9 & 11.2 \\
\hline 6 (SEG) & $\mathrm{Y}$ & $\mathrm{N}$ & $\mathrm{N}$ & $\mathrm{N}$ & 78.1 & 56.3 & 32.5 & 15.5 & 6.4 \\
\hline $7(\mathrm{CG})$ & $\mathrm{N}$ & $\mathrm{Y}$ & $\mathrm{N}$ & $\mathrm{N}$ & 78.4 & 53.7 & 30.5 & 13.6 & 5.8 \\
\hline 8 (NWG) & $\mathrm{Y}$ & $\mathrm{N}$ & $\mathrm{N}$ & $\mathrm{N}$ & 82.4 & 56.0 & 33.3 & 16.8 & 6.5 \\
\hline $9(\mathrm{SG})$ & $\mathrm{Y}$ & $\mathrm{N}$ & $\mathrm{N}$ & $\mathrm{N}$ & 85.3 & 57.5 & 32.8 & 13.8 & 5.7 \\
\hline $10(\mathrm{SG})$ & $\mathrm{Y}$ & $\mathrm{N}$ & $\mathrm{N}$ & $\mathrm{N}$ & 81.8 & 58.4 & 33.5 & 15.7 & 6.6 \\
\hline $11(\mathrm{CG})$ & $\mathrm{N}$ & $\mathrm{Y}$ & $\mathrm{N}$ & $\mathrm{N}$ & 76.7 & 52.9 & 30.7 & 16.5 & 6.5 \\
\hline $12(\mathrm{NG})$ & $\mathrm{Y}$ & $\mathrm{N}$ & $\mathrm{N}$ & $\mathrm{N}$ & 77.7 & 54.9 & 30.8 & 15.8 & 7.3 \\
\hline $13(\mathrm{NG})$ & $\mathrm{Y}$ & $\mathrm{N}$ & $\mathrm{N}$ & $\mathrm{N}$ & 83.4 & 57.8 & 32.9 & 14.7 & 6.0 \\
\hline
\end{tabular}

${ }^{1}$ The 1.5 and $270^{\circ}$ FTG indicates that there are no deciduous trees greater than $2 / 3$ height of the crop tree for $270^{\circ}$ of a 1.5 -m radius arc. The other definitions

Table 2. Light transmission (\%) for 13 different positions within a hypothetical aspen plot with a $3 \times 3$-m spacing (see Fig. 2). The plot was "grown" from 3 to $11 \mathrm{~cm} \mathrm{D}$. Light was modelled at 1 to $4.5-\mathrm{m}$ height, depending upon the size of the aspen. Four different Free-to-Grow criteria were considered for each of the positions where light was modelled. Light estimation was for $\mathbf{5 0 \%}$ diffuse light conditions from May 15 to Sept. 15 , at $54^{\circ}$ latitude.

\begin{tabular}{|c|c|c|c|c|c|c|c|c|c|}
\hline \multirow[b]{2}{*}{ Position } & \multicolumn{4}{|c|}{ Pass FTG Type ${ }^{1}$} & \multicolumn{5}{|c|}{ Mean $D_{30}$ of Aspen/Height of Light Estimate } \\
\hline & $\begin{array}{l}1.5 \mathrm{~m} \\
270^{\circ}\end{array}$ & $1 \mathrm{~m}$ & $1.5 \mathrm{~m}$ & $2.0 \mathrm{~m}$ & $\begin{array}{c}3 \mathrm{~cm} \\
1.0 \mathrm{~m}\end{array}$ & $\begin{array}{l}5 \mathrm{~cm} \\
1.5 \mathrm{~m}\end{array}$ & $\begin{array}{l}7 \mathrm{~cm} \\
2.5 \mathrm{~m}\end{array}$ & $\begin{array}{l}9 \mathrm{~cm} \\
3.5 \mathrm{~m}\end{array}$ & $\begin{array}{l}11 \mathrm{~cm} \\
4.5 \mathrm{~m}\end{array}$ \\
\hline $1(\mathrm{SG})$ & $\mathrm{Y}$ & $\mathrm{N}$ & $\mathrm{N}$ & $\mathrm{N}$ & 94.1 & 83.3 & 64.8 & 45.1 & 29.4 \\
\hline $2(\mathrm{SG})$ & $\mathrm{Y}$ & $\mathrm{Y}$ & $\mathrm{Y}$ & $\mathrm{N}$ & 91.4 & 76.0 & 61.5 & 45.8 & 33.8 \\
\hline 3 (CG) & $\mathrm{Y}$ & $\mathrm{Y}$ & $\mathrm{Y}$ & $\mathrm{Y}$ & 95.9 & 82.7 & 65.8 & 53.3 & 38.5 \\
\hline 4 (NG) & $\mathrm{Y}$ & $\mathrm{Y}$ & $\mathrm{Y}$ & $\mathrm{N}$ & 94.7 & 81.1 & 67.0 & 53.3 & 42.5 \\
\hline $5(\mathrm{NG})$ & $\mathrm{Y}$ & $\mathrm{N}$ & $\mathrm{N}$ & $\mathrm{N}$ & 95.3 & 84.8 & 69.1 & 53.7 & 42.4 \\
\hline 6 (SEG) & $\mathrm{Y}$ & $\mathrm{N}$ & $\mathrm{N}$ & $\mathrm{N}$ & 89.1 & 80.6 & 62.2 & 45.0 & 30.9 \\
\hline $7(\mathrm{CG})$ & $\mathrm{Y}$ & Y & Y & $\mathrm{N}$ & 88.3 & 76.9 & 60.0 & 44.2 & 31.5 \\
\hline 8 (NWG) & $\mathrm{Y}$ & $\mathrm{N}$ & $\mathrm{N}$ & $\mathrm{N}$ & 92.8 & 75.3 & 61.2 & 47.7 & 34.9 \\
\hline $9(\mathrm{SG})$ & $\mathrm{Y}$ & $\mathrm{N}$ & $\mathrm{N}$ & $\mathrm{N}$ & 93.8 & 82.7 & 63.3 & 42.8 & 26.3 \\
\hline $10(\mathrm{SG})$ & $\mathrm{Y}$ & $\mathrm{Y}$ & $\mathrm{N}$ & $\mathrm{N}$ & 87.1 & 78.9 & 63.0 & 46.6 & 30.5 \\
\hline $11(\mathrm{CG})$ & $\mathrm{Y}$ & $\mathrm{Y}$ & $\mathrm{Y}$ & $\mathrm{N}$ & 88.6 & 73.7 & 57.5 & 42.1 & 28.3 \\
\hline $12(\mathrm{NG})$ & $\mathrm{Y}$ & $\mathrm{Y}$ & $\mathrm{N}$ & $\mathrm{N}$ & 91.4 & 77.4 & 62.1 & 45.7 & 32.6 \\
\hline 13 (NG) & $\mathrm{Y}$ & $\mathrm{N}$ & $\mathrm{N}$ & $\mathrm{N}$ & 94.3 & 80.0 & 63.2 & 44.7 & 30.8 \\
\hline
\end{tabular}

${ }^{1}$ See Table 1.

Prediction of light using mensuration data was most successful using basal area (determined at $\mathrm{D}_{30} ; \mathrm{R}^{2}=0.869$ ). We broke this down to average stem diameter at $30 \mathrm{~cm}\left(\mathrm{D}_{30}\right)$ and density, as these are the measurements obtained in a regeneration assessment, and developed a predictive equation (Eq 2).

$$
\text { [2] } \quad \mathrm{I} / \mathrm{I}_{\mathrm{o}}=\exp \left(-\left(0.0000109 *\left(\mathrm{avD}_{30}\right)^{\left.2 * \text { Density })^{0.805}\right)}\right.\right.
$$

Here, $\mathrm{I} / \mathrm{I}_{\mathrm{o}}$ is light transmission, $\mathrm{avD}_{30}$ is the average stem diameter at $30 \mathrm{~cm}$ height, and density is in stems $/ \mathrm{ha}\left(\mathrm{R}^{2}=0.869\right.$, $\mathrm{n}=17$ ). Use of quadratic mean $\mathrm{D}_{30}$ did not improve the fit. This equation could be used to generate a light transmission table using stand average diameter and density as indexes. It should not be used out of the range of data from which it was developed (1.3 to $10-\mathrm{cm} \mathrm{D}_{30}, 2829$ to 40,585 stems/ha). Stand height and density were also good predictors of light transmission (data not shown), owing to the close relationship between $\mathrm{D}_{30}$ and height.

\section{Discussion}

The stand leaf area peaked (Fig. 4b) and light transmission was at a minimum (Fig. 4a) at about $15-25$ years. The rapid and heavy development of LAI after disturbance appears to be related to the dense suckering of aspen from established roots systems (DesRochers and Lieffers 2001) and the fact that short aspen stands have substantial horizontal overlap of crowns, thereby stacking more leaves into a given unit of canopy volume (Pinno et al 2001). Peterson and Peterson (1996) also reported an early peak in foliage biomass in young aspen stands. Therefore, some juvenile stands had an LAI near 6 and transmitted less than $5 \%$ of above canopy light. This level of subcanopy illumination would result in severe suppression or mortality of spruce saplings (Lieffers and Stadt 1994, Wright et al. 1998).

LAI decreased and light transmission increased after about age 25. This decline in leaf area with age has been reported for other species (Long and Smith 1992, Gower et al. 1996). Declining LAI, the importance of clumping of foliage in distinct crowns with age (Kucharik et al 1998), plus the development of crown shyness (Long and Smith 1992), results in increased light transmission and reduced competitive status of aspen in relation to understory spruce as stand age increas- 
Table 3. Light transmission (\%) for 13 different positions within a hypothetical aspen plot with a $2.5 \times 2.5-\mathrm{m}$ spacing (see Fig. 3). The plot was "grown" from 3 to $11 \mathrm{~cm} \mathrm{D}_{30}$. Light was modelled at 1 to 4.5 -m height, depending upon the size of the aspen. Four different Free-to-Grow criteria were considered for each of the positions where light was modelled. Light estimation was for $50 \%$ diffuse light conditions from May 15 to Sept. 15 , at $54^{\circ}$ latitude. The column on the right shows results from the same plot but at $44^{\circ}$ latitude.

\begin{tabular}{|c|c|c|c|c|c|c|c|c|c|c|}
\hline \multirow[b]{2}{*}{ Position } & \multicolumn{4}{|c|}{ Pass FTG Type ${ }^{1}$} & \multicolumn{5}{|c|}{ Mean $D_{30}$ of Aspen/Height of Light Estimate } & \multirow{2}{*}{$\begin{array}{l}\text { Lat. } 44 \\
11 \mathrm{~cm} \\
4.5 \mathrm{~m}\end{array}$} \\
\hline & $\begin{array}{l}1.5 \mathrm{~m} \\
270^{\circ}\end{array}$ & $1 \mathrm{~m}$ & $1.5 \mathrm{~m}$ & $2.0 \mathrm{~m}$ & $\begin{array}{l}3 \mathrm{~cm} \\
1.0 \mathrm{~m}\end{array}$ & $\begin{array}{l}5 \mathrm{~cm} \\
1.5 \mathrm{~m}\end{array}$ & $\begin{array}{c}7 \mathrm{~cm} \\
2.5 \mathrm{~m}\end{array}$ & $\begin{array}{l}9 \mathrm{~cm} \\
3.5 \mathrm{~m}\end{array}$ & $\begin{array}{l}11 \mathrm{~cm} \\
4.5 \mathrm{~m}\end{array}$ & \\
\hline $11 \mathrm{~T}-\mathrm{S}$ & $\mathrm{Y}$ & $\mathrm{N}$ & $\mathrm{N}$ & $\mathrm{N}$ & 85.6 & 67.8 & 49.2 & 31.2 & 18.9 & 19.3 \\
\hline $21 \mathrm{~T}-\mathrm{N}$ & $\mathrm{Y}$ & $\mathrm{N}$ & $\mathrm{N}$ & $\mathrm{N}$ & 87.6 & 67.3 & 48.9 & 31.6 & 19.8 & 22.9 \\
\hline $32 \mathrm{~T}-\mathrm{S}$ & $\mathrm{Y}$ & $\mathrm{Y}$ & $\mathrm{N}$ & $\mathrm{N}$ & 77.3 & 65.0 & 46.7 & 28.8 & 16.5 & 15.5 \\
\hline $42 \mathrm{~T}-\mathrm{N}$ & $\mathrm{Y}$ & Y & $\mathrm{N}$ & $\mathrm{N}$ & 88.7 & 61.7 & 42.8 & 27.2 & 17.3 & 20.2 \\
\hline $53 \mathrm{~T}-\mathrm{S}$ & Y & $\mathrm{N}$ & $\mathrm{N}$ & $\mathrm{N}$ & 75.9 & 54.4 & 34.7 & 18.6 & 9.3 & 9.5 \\
\hline $63 \mathrm{~T}-\mathrm{N}$ & Y & $\mathrm{N}$ & $\mathrm{N}$ & $\mathrm{N}$ & 87.7 & 65.2 & 48.4 & 30.3 & 18.2 & 21.2 \\
\hline 7 Open & $\mathrm{Y}$ & Y & $\mathrm{Y}$ & $\mathrm{Y}$ & 89.6 & 68.9 & 50.0 & 32.0 & 20.5 & 26.0 \\
\hline 8 Open & $\mathrm{Y}$ & Y & $\mathrm{Y}$ & $\mathrm{Y}$ & 91.6 & 69.5 & 52.0 & 35.5 & 24.7 & 27.5 \\
\hline $94 \mathrm{~T}$ & $\mathrm{~N}$ & $\mathrm{Y}$ & $\mathrm{N}$ & $\mathrm{N}$ & 81.6 & 63.6 & 42.0 & 24.8 & 12.6 & 11.1 \\
\hline 10 2T-NS & $\mathrm{N}$ & $\mathrm{Y}$ & $\mathrm{N}$ & $\mathrm{N}$ & 82.2 & 57.8 & 37.7 & 22.3 & 12.7 & 13.6 \\
\hline $112 \mathrm{~T}-\mathrm{NS}$ & $\mathrm{N}$ & $\mathrm{N}$ & $\mathrm{N}$ & $\mathrm{N}$ & 85.7 & 66.5 & 48.3 & 28.3 & 13.6 & 12.8 \\
\hline 12 2T-EW & $\mathrm{N}$ & $\mathrm{Y}$ & $\mathrm{N}$ & $\mathrm{N}$ & 89.4 & 68.1 & 48.0 & 30.7 & 19.7 & 19.6 \\
\hline $132 \mathrm{~T} \mathrm{EW}$ & $\mathrm{N}$ & $\mathrm{N}$ & $\mathrm{N}$ & $\mathrm{N}$ & 88.2 & 66.9 & 46.3 & 28.4 & 15.7 & 15.1 \\
\hline
\end{tabular}

${ }^{1}$ See Table 1 .

es. It is possible that LAI may be underestimated in maturing stands because of this crown clumping; however, data derived from measures of light transmission or from estimates of LAI appear to overlap (Fig. 4).

The light transmission data (Fig. 4a) suggest that in some aspen-dominated stands, understory spruce go through a competitive bottleneck of low light conditions at 15 to 25 years. It is noteworthy, however, that some of the 15 to 25 year-old stands transmitted ca. 20\% light, which is sufficient for survival and moderate height growth of spruce. This was also noted by Comeau (2001). With time, there is a gradual increase in light transmission, especially once the spruce reach the height of the aspen canopy (see Fig. 6).

Based upon the simulation analyses of hypothetical plots 1, 2 and 3 (Tables 1, 2 and 3), there appears to be only minor differences in light availability between acceptable and failing FTG positions. We have a high degree of confidence in these simulations because of the high correlation $\left(\mathrm{R}^{2}=0.92\right)$ between predicted and observed light in mapped juvenile stands (Pinno et al. 2001). Positions on the north side of gaps had slightly higher light transmission than on the south side of gaps. At high latitudes, the zone of higher solar radiation is offset from the centre of a canopy gap (Canham 1988), and this is exacerbated as the height of the trees increases. Also, as hardwood stems bend toward light gaps, it is likely that gaps 2 to $4 \mathrm{~m}$ across would eventually disappear as the trees grow. Thus, small-scale and detailed distancedependent competition indices may not be good predictors of future light competition. Plot size for a competition index must therefore change as competing trees become taller (Burton 1993). As much of the direct beam solar radiation over the growing season at high latitudes is lower than $45^{\circ}$ from horizontal, the plot radius to estimate stand conditions affecting direct beam light should be at least equal to the height of the competitors. This means a 10-m radius for competition estimation at the time of the competitive bottleneck at 15-25 years.

The overall stand density and tree size (Tables 1, 2 and 3) is a much better estimator of light transmission, and competition for light, than the FTG standards. As tree size has an impact on crown size and its leaf area, and density relates to the num- ber of tree crowns that are packed into a given area, light transmission is strongly related to both density and size. Our predictive equation for light (Equation 2) is therefore driven by basal area, or its components, density and diameter squared. This equation is also reasonable owing to the well-established relationship between sapwood area and leaf area. In juvenile stands, up to $11 \mathrm{~cm} \mathrm{D}_{30}$, virtually almost all of the basal area is sapwood area, therefore, an increase in basal area should mean an increase in leaf area and a decrease in light transmission. As heartwood was beginning to develop in trees greater than $11 \mathrm{~cm} \mathrm{D}_{30}$, Eq. 2 should not be used beyond this size. Comeau (2001) also noted the clear relationship between light transmission and basal area of juvenile aspen stands.

This study (Fig. 4) did not follow the LAI trajectories of individual stands but was based upon temporary sample plots of stands of a range of ages, and the stands were "grown" in the analyses (Tables 1,2, and 3) by simply changing the sizes of the trees. While we are not aware of density management diagrams for aspen, we anticipate that only plot 1 , at 2500 stems/ha and $11 \mathrm{~cm} \mathrm{D}_{30}$, would be near the self-thinning line. While this technique for "growing" stands has some limitations, the results from plot 2 suggest that 1100 well-spaced dominant trees/ha will deliver sufficient light to maintain good growth of the spruce. In this data set, $11 \mathrm{~cm} \mathrm{D}_{30}$ trees are approximately 25 years old and thus spruce in plot 2 would make it past the competitive bottleneck described above. While aspen does self thin rapidly, we currently have no means to predict the reduction in stand density with time.

As there are biodiversity and productivity benefits associated with mixed-species stands (Man and Lieffers 1999), it is desirable to have FTG standards that allow maintenance of both species. The mixedwood FTG standard using the $270^{\circ}$ arc was intended to allow some hardwoods within a $1.5-\mathrm{m}$ distance from the spruce. Virtually any position in plot 1 , except those positioned equidistant between the aspen trees, would meet this FTG standards. Assuming that all trees would still be alive by the time the stand reached $11 \mathrm{~cm} \mathrm{D}_{30}$, MIXLIGHT suggests that this stand will have low light transmission $(<10 \%)$ that would severely suppress or kill the spruce. These results, therefore, suggest that the use of the $270^{\circ}$ arc alone may not 


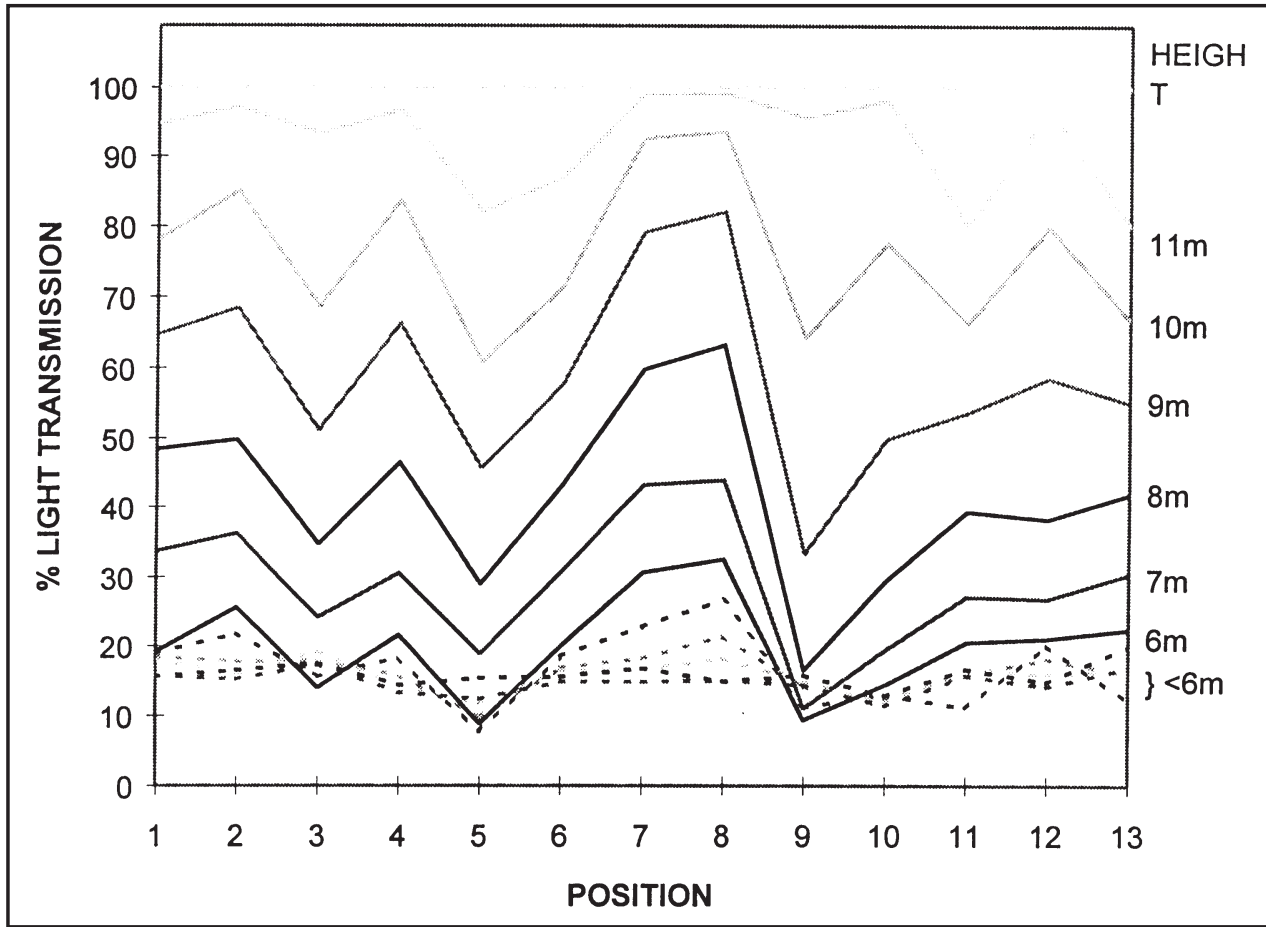

Fig. 5. Light transmission in relation to height above ground for stand 3 (See Fig. 3). The modelled stand had a $\mathrm{D}_{30}$ of $11 \mathrm{~cm}$ and was $11.9 \mathrm{~m}$ tall. Note that there is no connection between the 13 modelled positions; continuous lines are shown to assist readers in following light transmission at a given height. necessarily meet the FTG intent, even for the lowest goal of a FTG grow standard, i.e., to ensure survival of the conifer tree. In contrast, however, complete removal of all aspen trees in the three plots would be needed to achieve the 2-m radius definition of the conifer standard. This would achieve the opposite extreme, eliminating aspen. This far surpasses the survival standard definition of FTG.

In summary, none of the FTG definitions, based upon small plots, were able to predict the competitive impacts of aspen for light as the aspen becomes taller. Even the consideration of aspect in this analysis would only add a small increase in ability to prediction future light competition. As plots $10 \mathrm{~m}$ in radius would be needed to assess light regime at specific points in the understory for aspen stands $10 \mathrm{~m}$ tall (the time of the light bottleneck), it is unlikely that FTG definitions aimed at individual understory trees would be operationally practical. FTG in juvenile mixedwood stands should be assessed using a stand-average approach, such as measuring the density and size of aspen in stands or portions of stands.

\section{Acknowledgements}

We thank Ben Seaman, Jim Cuthbertson and Simon Landhäusser for assistance and Phil Comeau and Dave Patterson for suggestions on the manuscript. Weldwood of Canada Ltd., Weyerhaeuser Canada, NSERC and the NCE-SFM provided funding.

\section{References}

Alberta Environment. 2000. Alberta regeneration survey manual. Alberta Environment. Forest Management Division. Edmonton, AB.

Alberta Forest Service. 1992. Alberta regeneration survey manual. Alberta Forestry, Lands and Wildlife. Edmonton, AB.

Beckingham, J.D., I.G.W. Corns and J.H. Archibald. 1996. Field guide to ecosites of west-central Alberta. Nat. Resour. Can., Can. For. Serv., Northwest Reg., North. For. Cent., Edmonton, AB. Special Rep. 9.
Brand, D.G. 1986. A competition index for predicting the vigour of planted Douglas-fir in southwestern British Columbia. Can. J. For. Res. 16: 23-29.

Brand, D.G. and G.F Weetman. 1986. Standards for regeneration establishment in Canada: A case study for Douglas-fir. For. Chron. 62: 84-90.

Burton, P.J. 1993. Some limitations inherent to static indices of plant competition. Can. J. For. Res. 23: 2141-2152.

Canham, D.D. 1988. An index for understory light levels in and around canopy gaps. Ecology 69: 1634-1638.

Constabel, A. J. and V.J. Lieffers. 1996. Seasonal patterns of light transmission through boreal mixedwood canopies. Can. J. For. Res. 1008-1014.

Comeau, P.G. 2001. Relationship between stand parameters and understory light in boreal aspen stands. B.C. J. Ecosystems and Management. In press.

Comeau, P.G., T.F. Braumandl and C.-Y. Xie. 1993. Effects of overtopping vegetation on light availability and Engelmann spruce (Picea engelmannii) seedlings. Can. J. For. Res. 23: 2044-2048.

DeLong, H.B., V.J. Lieffers and P.V. Blenis. 1997. Microsite effects on first-year establishment and overwinter survival of white spruce in aspen-dominated boreal mixedwoods. Can. J. For. Res. 27: 1452-1457.

DesRochers, A. and V.J. Lieffers. 2001. Root biomass of regenerating aspen (Populus tremuloides Michx.) stands in Alberta. Can. J. For. Res. 31: 1012-1018.

Eis, S. 1981. Effect of vegetative competition on regeneration of white spruce. Can. J. For. Res. 11: 1-8.

Gower, S.T., R.E. McMurtrie and D. Murty. 1996. Aboveground net primary production decline with stand age: potential causes. TREE 11: 378-382.

Jarvis, P.G and J.W. Leverenz. 1983. Productivity of temperate, deciduous and evergreen forests. In O.L. Lang, P.S. Nobel, C.B. Osmond and H. Zielgler (eds.). Physiological plant ecology IV. Ecosystem processes: Mineral cycling, productivity and Man's influence. pp. 243-280. Encyclopedia of plant physiology, New Series, Vol. 12D Springer-Verlag, Berlin.

Kucharik, C.J., J.M. Norman and S.T. Gower. 1998. Measurements of branch area and adjusting leaf area index measurements. Ag. For. Meteorol 91: 69-88. 
Lieffers, V.J., C. Messier, K.J. Stadt, F. Gendron and P.G. Comeau. 1999. Predicting and managing light in the understory of boreal forests. Can. J. For. Res. 29: 796-811.

Lieffers, V.J. and K.J Stadt. 1994. Growth of understory Picea glauca, Calamagrostis canadensis, and Epilobium angustifolium in relation to overstory light transmission. Can. J. For. Res. 24: 1193-1198. Logan, K.T. 1969. Growth of tree seedling as affected by light intensity. IV black spruce, white spruce, balsam fir and eastern white cedar. Can. For. Serv. Publ. 1256.

Long, J.N. and F.W. Smith. 1992. Volume increment in Pinus contorta var. latifolia, the influence of stand development and crown dynamics. For. Ecol. Manage. 53: 53-64.

MacDonald, G.B. and G.F. Weetman. 1993. Functional growth analysis of conifer seedling responses to competing vegetation. For. Chron. 69: 64-70.

Man, R. and V.J. Lieffers. 1999. Are mixtures of aspen and white spruce more productive than single species stands? For. Chron. 75: 505-513.

Messier, C., S. Parent and Y. Bergeron. 1998. Characterization of understory light environment in closed mixed boreal forests: effects of overstory and understory vegetation. J. Veg. Sci. 9: 511-520.

Peterson, E.B. and N.M Peterson. 1996. Ecology and silviculture of trembling aspen. In P.G. Comeau, G.J. Harper, M.E. Blache, J.O. Boateng and K.D. Thomas (eds.). Ecology and management of British Columbia hardwoods. pp. 31-52. B.C. Min. of Forests, Research Branch, Victoria. FRDA Report 255.
Pierce, L.L. and S.W. Running. 1988. Rapid estimation of coniferous forest leaf area index using a portable integrating radiometer. Ecology, 69: 1762-1767.

Pinno, B.D. 2000. Crown characteristics and understory light in young trembling aspen stands. M.Sc. Thesis, University of Alberta. 85 p. Pinno, B.D., V.J. Lieffers and K.J. Stadt. 2001. Measuring and modeling the crown and light transmission characteristics of juvenile aspen. Can. J. For. Res. In Press.

Stadt, K.J. and V.J. Lieffers. 2000. MIXLIGHT: A flexible light transmission model for mixed-species forest stands. Agric. For. Meteor. 102: 235-252.

Stevens, M.D. and M.H. Unsworth. 1980. The angular distribution and interception of diffuse solar radiation below overcast skies. Quart. J. Royal Meteorol. Soc. 106: 57-61.

Tanner, D., S.C. DeLong and A. Eastham. 1996. Investigations of planting wite spruce under a trembling aspen canopy. In P.G Comeau and K.D. Thomas (eds.). Silviculture of temperate and boreal broadleaf-conifer mixtures. pp. 114-121. Land Manage. Handbook 36. B.C. Ministry of Forests, Victoria, BC.

Wright, E.F., K.D. Coates, C.D. Canham and P. Bartemucci. 1998. Species variability in growth response to light across climatic regions in northwestern British Columbia. Can. J. For. Res. 28: 871-886. 